\title{
木造土壁の各部仕様が防耐火性能に及ぼす影響 \\ INFULUENCES OF CONSTRUCTION DETAILS ON THE FIRE RESISTANCE OF TRADITIONAL WOOD/SOIL WALLS
}

\author{
安井 昇, 長谷見 雄二**, 秋月通孝***, 馬屋原 敦****, 大西 卓****, 上島 基 英**** \\ 畑 俊 充*****，木村忠 紀******，田村 佳 英*******，村上＼cjkstart博******** \\ Noboru YASUI, Yuji HASEMI, Michitaka AKIZUKI, Atsushi UMAYAHARA,Suguru OHNISHI, \\ Motohide KAMIJIMA, Toshimitsu HATA, Tadanori KIMURA, \\ Yoshihide TAMURA and Hiroshi MURAKAMI
}

\begin{abstract}
Fire resistance tests are conducted on small-scale specimens of wood/soil wall assembly with different construction details as a basis for developing code-acceptable traditional wooden constructions. The tests have revealed significant influence of both-side plastering of soil wall, thickness and water content of the soil layer and various reinforcements of timber/soil layer interface on the prevention of the heat and flame penetration through a wood/soil wall. It has been also clarified that charring of the timber element, a major cause for the collapse of the wall due to fire, can be reduced by the protection of the load-bearing timber elements by soil or wood or by design considerations reducing fire exposure of the timber element.
\end{abstract}

Keywords : wood/soil wall, traditional town house, external wall,thermal insulation, integrity, charring rate 木造土壁、伝統町家、外壁、遮熱性、遮炎性、炭化速度

\section{1. はじめに}

木造土壁構法等の日本古来の伝統的木造建築については、戦後、 建築基準法等による木造の制限が導入されて以来、伝統的仕様のま ま、またはその延長上で防火性能を向上させるための系統的な研究 開発はほとんど行われてこなかった。現行の建策基準法では、木造 土壁は防火構造の仕様規定（平成 13 年国土交通省告示第 1684 号） に「土藏造」「土塗真壁造で裏返し塗りをしたもの（ただし、両面 の塗り厚がそれぞれ $20 \mathrm{~mm}$ 以上)」の 2 仕様のみが、位膡づけられ ているにすぎず、防火関係大臣認定取得の試みもされてこなから た。このため、木造土壁では町家形式の新築が事実上不可能なばか りでなく、京都等の攵史的市街地に建つ伝統的町家のほとんどが既 存不適格建築物であり、伝統仕様での大規模改修や新築の道は閉ざ されている。さらに、歴史的市街地でも指定された容積率を有効利 用するには、事実上、準耐火構造以上を必要とする場合が多いにも かかわらず、木造土壁では、それを達成できる見通しがたてられな かったことが、 $\mathrm{RC}$ 造・S 造への建て替えを加速している。伝統仕 様の範囲またはその延長上で、防火構造・準耐火構造の木造土壁を 開発できれば、これらの問題解決の突破口になる可能性がある。ま た、伝統的な木造土壁構法は、建築資源の再生・再利用可能性が高
く、室内環境污染物質をほとんど含まない自然素材である等の観点 から、再評価の機運にあり、火災に強い木造土壁構法や、既存建物 の防火補強技術を開発整備する意義は大きい。

これまで、木造土壁の防火性能について、わずかに行われてきた 研究をみると、山田ら ${ }^{1}$ は、約 $1 \mathrm{~m}$ 角の試験体を製作し、JIS A 1304 「建築構造部分の耐火試験方法」に基づいた加熱試験を行い、柱に ちりじゃくり、をつた上で土壁を裹返し塗りし、表面に下見板を張 れば、裹面温度が $260^{\circ} \mathrm{Cを}$ 越えるのに約 75 分を要することを確認し た。また、筆者ら゙2は、京町家の再生事例 ${ }^{3)}$ で施工された木造土壁と 同仕様の実大試験体を製作し、柱に長期許容応力度に相当する荷重 を載荷しながら ISO834 標準加熱曲線に準じた加熱を行い、木造土 壁でも、塗り厚を確保したり、柱の防火被覆を行えば、準耐火構造 まで実現できる可能性があることを明らかにした。

また、木造土壁構法の上等な仕事では、経年変化による柱と土壁 の取り合い部の覙間の発生を予防するため、伝統的に柱にちりじゃ くりをつけたり、中塗り時に細い割竹に麻布を旗状につけた布連 （のれん）を柱のちり部に打ち、土と一緒に麻布を塗り込むという 手法がとられて来た。これらは、特に防火的補強を意識した手法で はないが、隙間を防止することは防火的にも有勃であり、伝統的仕
* 早稲田大学大学院理工学研究科 大学院生・工修

** 早稲田大学理工学部建築学科 教授. 工博

*** 大成建設(侏) 工修 大成建設(侏) 工修

**** 早稲田大学大学院理工学研究科 大学院生

******京都大学木質科学研究所 助手 $\cdot$ 農博

****** 京都府建築工業協同組合 理事

******* 関西木造住文化研究会 代表幹事

******** 京都左官協同組合 前理事長
Graduate Student, Waseda University, M. Eng

Prof., School of Science and Engineering, Waseda University, Dr. Eng. Taisei Corporation, M. Eng.

(Formerly Graduate Student, Waseda University)

Graduate Student, Waseda University

Research Assoc., Wood Research Institute, Kyoto University, Dr. Agr. Director, Kyoto Cooperative Union of Carpenters

Secretariat, Kansai Association for Research in Traditional Housings Former Chairman, Kyoto Plasterers' Association 
様には防火性能向上を期待できる要素もある。しかし、布連は新 築・既存建物を問おず利用できるのに対し、柱のちりじゃくりは、 新筑時には容易に使えても、既存柱にもともと設けられていなけれ ば改修への利用が困難であるなど、伝統構法の防火的改良が要請さ れる場面への適用可能性は様々である。

本研究は、建物の新築及び既存建物改修に適用できる防火的な土 壁の仕様を開発する基盤的情報を整備するために、木造土壁の仕様 や納まりが防火性能に及ほすす影響を小型試験体による加熱試験で系 統的に明らかにしようとするものである。

\section{2. 実験幛画}

建築基準法による外壁の防火性能評価基準は、(1)軸組の変形（非 損傷性) (2)裏面の温度上昇（遮熱性）、(3)火炎の貫通（遮炎性 : 準 耐火構造以上）の 3 点である。これらすべてを調べるためには実大 規模の試験体で載荷加熱試験を行う必要があるが、試験体製作や運 搬等、困難な面も多いと考えられたので、今回の実験では、小規模 な試験体（W915mm $\times$ H900mm）を製作し、試験体のスケールに あまり影響されない土壁の遮熱性と遮炎性について系統的に調べ、 載荷と変形評価を必要とする非損傷性は、柱の炭化が大きな影響を 与えれると考えられるので2、それを遅延させる方法を検討した。

\section{1 試験体の設計}

試験体の仕様概要を表 1 に、構成を図 1 に示す。試験体は、土 台・柱・枌で構成された軸組に縦貫、横貫（スギ $15 \times 90 \mathrm{~mm}$ ）を それぞれ中央に取り付け、木舞竹（真竹）を編んだ上に土を塗っ た。既往の実験 ${ }^{122}$ によると、土壁の遮熱性・遮炎性には、

(1)裏返し塗りの有無・土壁の塗り厚・土の含水率・土の種類

(2)外部仕上げの有無

(3)柱と土壁の取り合い部の処理

が影響すると予想され、非損傷性には、

(4)柱の寸法・柱の樹種

(5)柱の防火被覆種類

(6)柱と土壁の位圈関係

(7)柱の背割りの有無

が影響すると予想されたので、これらを比較できるように合計 17 体の試験体を製作した。以下に試験体の詳細を述べる。

(1)襄返し濹りの有無・土壁の㳂り厚・土の種類・土の含水率

土壁の塗り厚は、裏返し塗りをしない仕様では $30 \mathrm{~mm} 、 40 \mathrm{~mm}$ と し、裏返し塗りをした仕様では総厚を $50 \mathrm{~mm} 、 60 \mathrm{~mm} 、 78 \mathrm{~mm}$ とし た。荒壁土、中塗土ともに、試験体No.1のみ埼玉県深谷産の荒木 田土、それ以外は、京都産の深草土とした。荒壁土は、試験体 No.2

\section{表 1、試験体概要一覧}

\begin{tabular}{|c|c|c|c|c|c|c|c|c|c|}
\hline \multirow{2}{*}{\begin{tabular}{|c|} 
試験体 \\
No. \\
\end{tabular}} & \multirow[t]{2}{*}{ 土壁仕棦 } & \multirow[t]{2}{*}{ 外部仕上 } & \multicolumn{2}{|c|}{ 柱材料/寸法*1 } & \multirow[t]{2}{*}{ 柱防火被覆 } & \multicolumn{2}{|c|}{ ちり周り部補強方法*2 } & \multirow{2}{*}{ 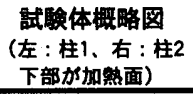 } & \multirow{2}{*}{$\begin{array}{l}\text { 加熱 } \\
\text { 時間 } \\
\end{array}$} \\
\hline & & & 柱1 & 柱2 & & 柱1 & 柱2 & & \\
\hline 1 & 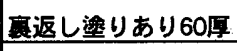 & - & ヒノキ/120 & $ヒ ノ キ / 105$ & - & ちりじゃくり6 & 与りじゃくり6 & & 60分 \\
\hline 2 & 夏返し塗りあり60厚 & - & 주 $/ 120$ & クリ/120 & - & ちりじゃくり6 & ちりじやくり6 & & 60分 \\
\hline 3 & 衰返し塗りあり60厚 & - & $x \neq 1 / 120$ & 쥬/105 & - & ちりじやくり6 & ちりじゃ<り6 & & 60分 \\
\hline 4 & 負返し湮りあり50厚 & 杉12厚 & 주 $/ 120$ & 米ヒバ/120 & - & ちりじゃくり6 & ちりじゃくり6 & & 60分 \\
\hline 5 & 寡返し塗りあり60厚 & - & 쥬/120 & ヒノキ/120 & - & - & - & & 60分 \\
\hline 6 & 軎返し治りあり78厚 & - & 즈 $/ 120$ & ケヤキ/120 & - & ちりじゃくり6 & ちりじゃくり6 & & 60分 \\
\hline 7 & 票返し塗りなし30曺 & - & 주/120 & 集成材 $/ 120$ & - & ちりじゃくり9 & ちりじゃ<り6 & & 60分 \\
\hline 8 & 寡返し塗りなし30厚 & 粀12厚 & 쥬/120 & 米ツガ/120 & - & ちりじゃ<り6 & ちりじゃくり6 & & 60分 \\
\hline 9 & 䒠返し湮りなし40厚 & - & 쥬/105@ & 즈 & - & 布連（のれん） & 布連 (のれん) & & 60分 \\
\hline 10 & 表返し㳂りなし40厚 & - & 즈 $\neq / 105$ & 쥬 & - & ちりじゃ<り6 & 5りじゃ<り6 & & 60分 \\
\hline 11 & 寡返し塗りなし40厚 & - & 즈 $/ 105 \bigcirc$ & 주 $/ 1050$ & \begin{tabular}{|c}
$\begin{array}{c}\text { 準不燃処理 } \\
\text { (柱2) }\end{array}$ \\
\end{tabular} & 布連（のれん） & 布連 (のれん) & & 60 分 \\
\hline 12 & 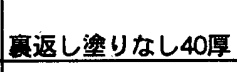 & - & 쥬 $/ 105$ & 주 $7 / 105$ & - & 7ルミ7ング $15 \times 15$ & 栈木 $15 \times 15$ & $m=$ & 60分 \\
\hline 13 & 荲返し塗りあり60厚 & - & 즈 $/ 120$ & 즈 $\neq / 105$ & 杉15厚(柱2) & 5りじゃくり6 & ちりじゃくり6 & & 60分 \\
\hline 14 & 裹返し塣りあり60厚 & - & $\pi \neq / 120$ & 즈 $/ 105$ & $\begin{array}{l}\text { 土20厚(柱1) } \\
\text { 土35厚(柱 } 2 \text { ) }\end{array}$ & - & - & खाय & 60 分 \\
\hline 15 & 䒠返し漜りなし40厚 & - & 쥬/120 & 즈キ1/105 & 杉15厚(柱2) & ちりじゃくり9 & ちりじゃ<り9 & & 30分 \\
\hline 16 & 襄返し湮りなし40厚 & - & $\pi \neq / 120$ & 쥬/105 & - & ちりじゃくり6 & ちりじゃ<り 6 & & 30分 \\
\hline 17 & |裹汳し澳りなし40厚 & - & 55 & スキ/105 & $\begin{array}{c}\text { 防火涂料 } \\
\text { (柱1) }\end{array}$ & 布連（のれん） & 布連（のれ & & $3 c$ \\
\hline
\end{tabular}

*1：柱材料/寸法攔の○印は柱に背割りがあることを示す。

*2 : ちりじゃくりの後の数字は深さ $(\mathrm{mm})$ を表す。 


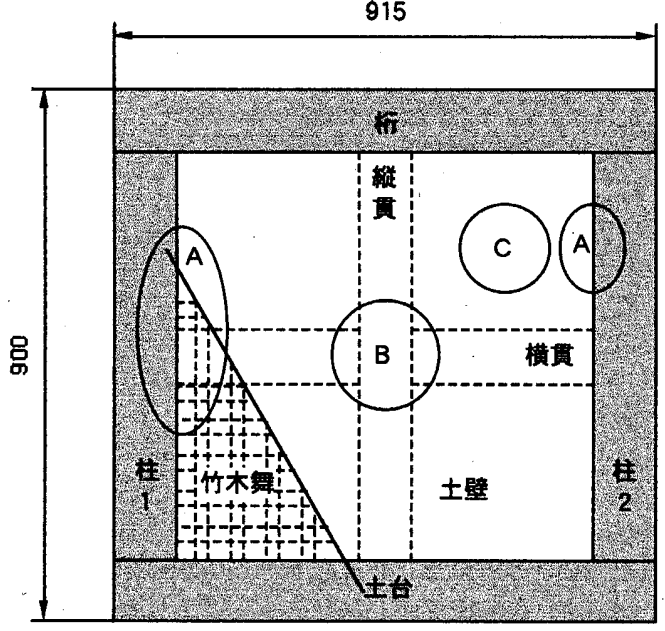

図 1 証験体構成図（直返し塗りがない場合・加熱面からみる）

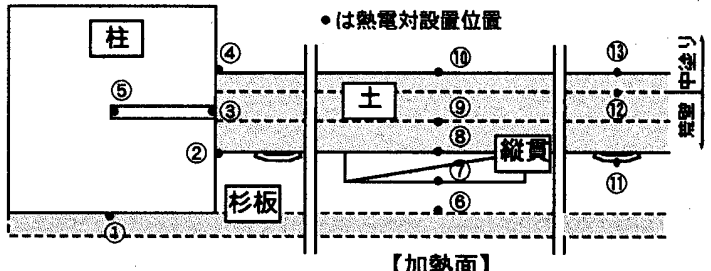

【加熱面】

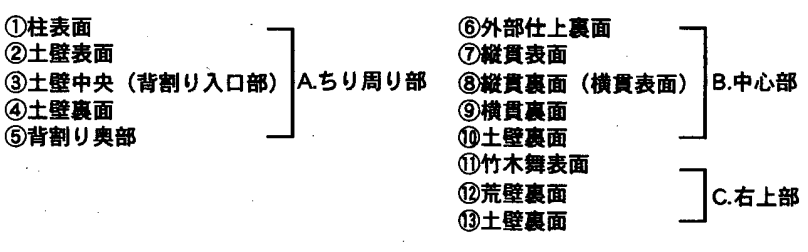

単位: $\mathrm{mm}$
〜 8で䓪スサをまぜて約半年間寝かせた土とそうでない土を約 $2: 1$ の割合で混合したものを使用し、それ以外は夢かせていない新しい 土を使用した。中塗土は試験体 No.2 のみ深草土に珠藻土を約 3 割 混入したものを使用した。また、土の含水率が裹面温度の上昇に与 える影響を調べるために、試験体No.9では、他の試験体と同条件 で乾燥養生後、実験直前に土の含水率が $10 \%$ （他の裏返し塗りをし ていない試験体の含水率は $2.4 \sim 2.5 \%$ ）になるよう非加熱面（室 内側）から水を土壁全体に含浸させて実験を行った。

（2）外部仕上げの有無

土壁表面に板材を張った場合の土壁や柱への加熱遅延効果を調べ るために、試験体 No.4 と No.8の土壁の加熱面（屋外側）に厚み $12 \mathrm{~mm}$ 、働き幅 $150 \mathrm{~mm}$ の杉板(含水率約 $15 \%$ )を相じゃくりで縱張 りした。

\section{(3)柱と土壁の取り合い部の処理}

柱と土壁の取り合い部は、隙間等の防火的弱点になり易い。そこ

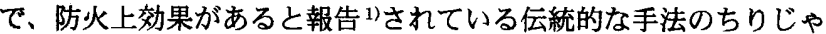
くりを柱につけたり、中塗り時に柱に布連打ち、15×15mm 杉栈 木打ち、 L-15 × $15 \times 1.5 \mathrm{~mm}$ アルミアングル打ちを行って、この 部分の補強方法を検討した。

\section{(4)柱の寸法・柱の樹種}

柱の寸法は一般的な軸組木造住宅で使用されている $105 \mathrm{~mm}$ 角、 $120 \mathrm{~mm}$ 角とした。また、材種毎の炭化深さや炭化速度を比較でき るように、杉、ヒノキ、米ヒバ、米ツガ、クリ、ケヤキ、ホワイト ウッド集成材をそれぞれ使用した。

\section{(5)柱の防火被覆の種類}

載荷加熱された軸組の崩壊を防止する手段として、柱の炭化を減 らすことが挙げられる。その方法としては、(1)柱を防火被覆して直 接加熱を受けないようにする、(2)柱自体への着火防止・燃焼抑制措 置を行うことが考えられる。そこで、(1)について、試験体No.13 No.15 の柱に $15 \mathrm{~mm}$ 厚の杉板を防火被覆として張り付け、No.14 の柱の加熱面を土壁で被覆して、大壁とした。また、(2)について、 鵤験体 No.11 で $15 \mathrm{~mm}$ 厚までの板材の淮不燃材化処理方法として 実績のある含水ホウ酸塩・無機リン酸系薬剤処理を柱全体に施し、 No.17で防火淎料の中で燃焼抑制効果が高いと報告されている4)発
泡系塗料を柱表面に $400 \mathrm{~g} / \mathrm{m}^{2}$ 塗布した。

\section{(6)柱と土壁の位置関係}

一般的な施工では、土壁の位置は柱の中心付近で、柱と土壁の加 熱側（屋外側）のちり寸法は、約 $20 \sim 40 \mathrm{~mm}$ となる。しかし、こ の寸法を小さくすれば、直接火災加熱される柱の表面積を隇らすこ とができ、軸組の崩壊の原因となる柱の炭化を緩和できると考えら れたので、試験体 No.13 と No.16 では、土壁を一般的な施工より も柱に対して加熱側に配置し、柱と土壁のちり寸法を $15 \mathrm{~mm}$ とした。 (7)柱の背割り

背割りした柱が 4 面加熱されると、背割りがない場合より、炭化 面積が増加すると報告されている5。土壁では、背割りは土の中に 配置されるが、塗り方や仕様によっては、露出することも考えられ るので、その比較ができるよう試験体 No.17 では背割りを土壁より 加熱側に配置して、背割りが直接加熱されるようにした。また、試 験体 No.9 11 では、土壁の中に背割りが配置されるようにした。

\section{2 試験体の製作及び実験時期}

軸組の製作及び下地組を京都府建築協同工業組合が、土塗りを京 都左官協同組合が行った。試験体No.1〜8は、平成 13 年 8 月下旬 より製作を開始し、軸組組立 $\rightarrow$ 下地木舞竹編み $\rightarrow$ 荒壁塗り（室内

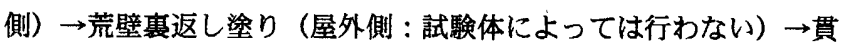
伏せ・ちり周り $\rightarrow$ 中塗り（表面に板を張らない荒壁を塗った上の み） $\rightarrow$ 表面板張りの順で施工し、雨かかりのない屋外で自然乾燥養 生後、平成 13 年 9 月下旬から 10 月下旬にかけて京都大学木質科学 研究所の耐火炉 (W1350mm $\times$ H1900mm)を用いて実験を行った。 また、試験体No.9〜 17 は、平成 14 年 8 月中旬から製作を開始し、 同様の工程を経て、風通しのよい屋内で自然乾燥養生後、平成 14 年 9 月下旬に実験を行った。

\section{3 実験方法}

\subsection{1 加熱方法}

加熱は、ISO834 標準加熱曲線に準じて行った。加熱時間は、試 験体 No.1〜 14は、現行の法令上、一般木造で達成できる最高の位 置付けの準耐火構造を意識して 60 分間とし、試験体 No. $15 \sim 17$ 


\begin{tabular}{|c|c|c|c|c|c|c|c|c|c|c|c|}
\hline \multirow{2}{*}{$\begin{array}{l}\text { 玨聅体 } \\
\text { No. }\end{array}$} & \multirow[t]{2}{*}{ 土譬仕様 } & \multirow{2}{*}{$\begin{array}{c}\text { 外部仕上または } \\
\text { 柱防火被洹 }\end{array}$} & \multirow{2}{*}{\begin{tabular}{|l|} 
加熱 \\
時間
\end{tabular}} & \multirow{2}{*}{$\begin{array}{l}\text { 火炎 } \\
\text { 貫通 }\end{array}$} & \multicolumn{2}{|c|}{ 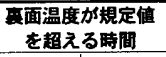 } & \multirow{2}{*}{ 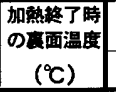 } & \multicolumn{2}{|c|}{ 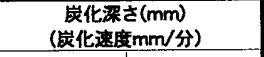 } & \multicolumn{2}{|c|}{ 含水事(\%) } \\
\hline & & & & & $160^{\circ} \mathrm{C}$ & $200^{\circ} \mathrm{C}$ & & 柱1 & 柱2 & 柱平均 & 土璧 \\
\hline 1 & 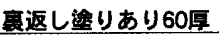 & - & 60分 & \multirow{9}{*}{ な } & 越えず & 越えず & 89 & $36.4 \quad(0.61)$ & $34.3 \quad(0.57)$ & 17.2 & 1.2 \\
\hline 2 & 真返し塗りあり60厚 & - & 60分 & & 埱えず & 越えず & 122 & $33.6 \quad(0.56)$ & $36.4 \quad(0.61)$ & 17.3 & 4.3 \\
\hline 3 & 恵返し㳂りあり60厚 & - & 60分 & & 越えず & 越えず & 117 & $31.4(0.52)$ & $33.6 \quad(0.56)$ & 19 & 2.5 \\
\hline 4 & 要返し策りあり50厚 & 杉12呈 & 60分 & & 䞡えす & 越えず & 94 & $27.1(0.45)$ & $29.3 \quad(0.49)$ & 15.3 & 2.5 \\
\hline 5 & 是返し & - & 60分 & & 59分 & 越えず & 161 & $31.4 \quad(0.52)$ & $31.4 \quad(0.52)$ & 19.6 & 2.5 \\
\hline 6 & 寅返し治りあり78厚 & - & 60分 & & 越えず & 越えず & 84 & $30.0 \quad(0.50)$ & $32.8 \quad(0.55)$ & 18.5 & 2.5 \\
\hline 7 & 2し 30 厚 & - & 60分 & & 36分 & 43分 & 277 & $34.3 \quad(0.57)$ & $35.0 \quad(0.58)$ & 15.5 & 2.5 \\
\hline 8. & （ 30 厘 & 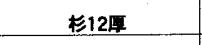 & 60分 & & 44分 & 49分 & 296 & $30.0 \quad(0.50)$ & $34.3 \quad(0.57)$ & 16.2 & 2.5 \\
\hline 9 & 自返し洎りなし40厚 & - & 60分 & & 37 分 & 39分 & 405 & $27.8 \quad(0.46)$ & $32.8 \quad(0.55)$ & 26.9 & 10.0 \\
\hline 10 & 表返し & - & 60分 & \multirow[t]{3}{*}{ ᄂ } & 34分 & 38分 & 360 & $36.4 \quad(0.61)$ & $32.8(0.55)$ & 15.7 & 2.4 \\
\hline 11 & なし40厘 & 勉处理 & 60分 & & 27 分 & 31分 & 405 & $41.4 \quad(0.69)$ & $32.1 \quad(0.54)$ & 13.9 & 2.4 \\
\hline 12 & 毫返し奥りなし40厚 & - & 60 分 & & 25分 & 30 分 & 395 & $28.6(0.48)$ & $36.4 \quad(0.61)$ & 15.0 & 2.4 \\
\hline 13 & 軍返し & 杉15咱(柱2) & 60 分 & & 趛えす & 越えず & 100 & $32.1 \quad(0.54)$ & $20.0 \quad(0.33)$ & 14.2 & 2.8 \\
\hline 14 & りあり60量 & ors(t) & 60分 & & 越えす & 越えず & 101 & $25.7,(0.43)$ & $5.0 \quad(0.08)$ & 16.6 & 2.8 \\
\hline 15 & 更返し酒りなし40厚 & 杉15厘(柱2) & 30 分 & & 25分 & 29分 & 205 & $25.0 \quad(0.83)$ & $13.6 \quad(0.45)$ & 14.2 & 2.4 \\
\hline 16 & 患返し & - & 30 分 & & 越えず & 越えず & 98 & $20.7 \quad(0.69)$ & $17.9 \quad(0.60)$ & 14.2 & 2.4 \\
\hline 17 & 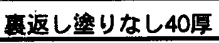 & 防火盗料(住1) & 30分 & & 越えず & 27 分 & 200 & $21.4 \quad(0.71)$ & $25.0 \quad(0.83)$ & 14.8 & 2.4 \\
\hline
\end{tabular}

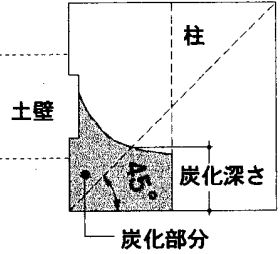

柱の炭化深さは、加熱終了 後、直ちに注水消火し、炭化 部分を取り除いたのち、2 面 加熱の影響を調べるために上 図の位置て測定した。また、炭 化速度は、この炭化深さを表2 の加熱時間て除して求めた。

図 2 炭化深さ测定位置
は、防火構造になり得る条件を明らかにするために 30 分間とした。

\subsection{2 測定項目}

図 1 に示す位置に $\phi 0.68 \mathrm{~mm}$ の $\mathrm{K}$ タイプ(CA)熱電対を最大 21 点 （試験体仕様により異なる）設置し、15秒間隔で計測した。熱電対 は、防火上の弱点となりやすい柱と土壁の取り合い部と土壁中央付 近にそれぞれ、加熱面（屋外側）から非加熱面（室内面）にかけて 断面方向に密に配置した。その他、炉内温度の測定、試験体表面及 び裏面の目視観察、試験体裏面の熱映像記録、ビデオ及びカメラに よる映像記録を行った。また、土壁の防火性能には、土及び軸組木材 の含水率が影響すると考えられるので、仕様ごとにサンプルを作成 し、試験体と同条件で養生をした後、絶乾法で含水率を測定した。

\section{4 防耐火性能の評価}

遮熱性は土壁中央部（図 1 のB部：縦貫と横貫の交差部）裹面と 土壁右上部（図 1 のC部 : 木舞部）裹面に取り付けた熱電対の温度 が国土交通省指定性能評価機関の「防耐火性能試験・評価業務方法 書」に定められた規定值注 1 (平均 : 初期温度 $+140^{\circ} \mathrm{C}$ 、最高 : 初期 温度 $+180^{\circ} \mathrm{C}$ ) に達する時間で評価した。遮炎性は非加熱側からの 目視観察で判断した。また、本実験では、試験体が約 $900 \mathrm{~mm}$ 角と 小さいため、法令による防耐火性能評価項目のうち、載荷と変形評 価を必要とする非損傷性は直接把握できないが、これに大きな影響 を与えると考えられる柱の炭化状況を測定した。

\section{3. 実験結果及び考察}

\section{1 実験結果概要}

実験結果一覧を表 2 に、代表的な仕様（試験体 No.3,10)の土壁内 部及び裹面温度変化を図 3 に示す。

実験中の試験体非加熟面をみると、柱と土壁の取り合い部（以 後、ちり周り部) は、加熱開始後 3 分を経過した頃から土や木材中 の水分に由来すると考えられる湯気が急激に吹き出し、その後、 徐々に減少した。この湯気の量は、ちり周り部にのれん打ち、栈木 打ち、アルミアングル打ちをした試験体の方が、何も処理をしな かった試験体より少なかった。また、土壁中央部は加熱により土が

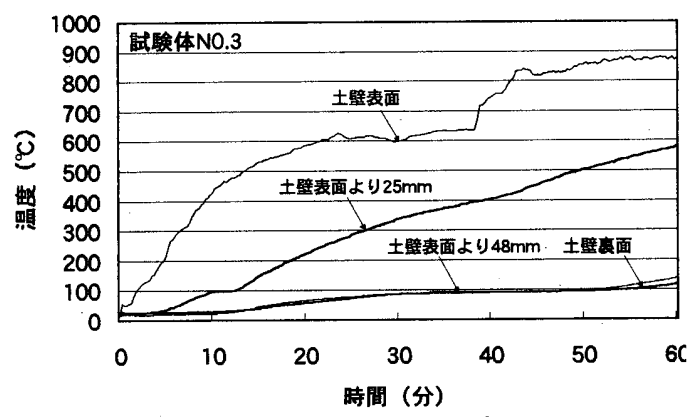

(a)裏返し塗りあり $60 \mathrm{~mm}$ 土壁

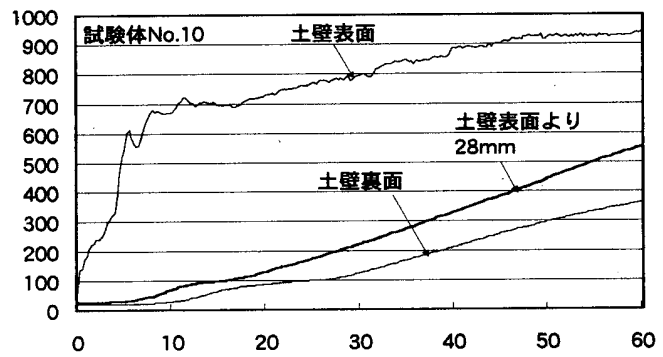

（b)裹返し塗りなし $40 \mathrm{~mm}$ 厚土壁

图 3 代表的な仕様の土壁内部及び裹面温度変化

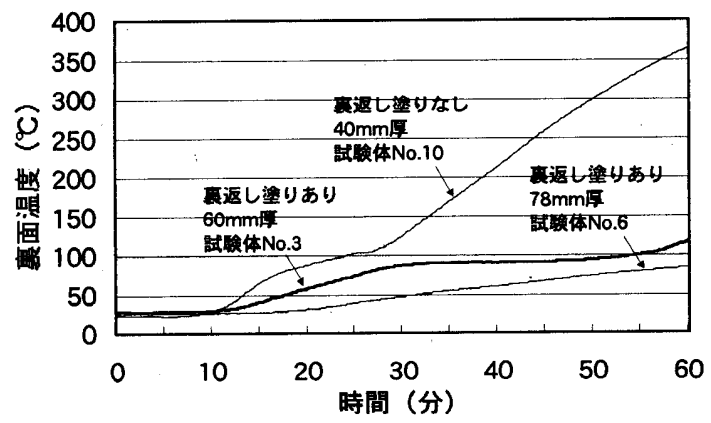

图 4 裏返し塗りの有無・塗り厚による裹面温度変化 
多少黒く変色したものの加熱中の土壁の割れ、脱落はなく、すべて の試験体において、火炎の貫通は起こらなかった。

土壁の裏面温度は、裏返し塗りをした場合、60 分間加熱を行って も遮熱性評価の規定值 $160^{\circ} \mathrm{C}$ をきく下回った。一方、裏返し塗り をしていない場合、加熱開始後 25 分〜 36 分に $160^{\circ} \mathrm{C} 、 27$ 分〜

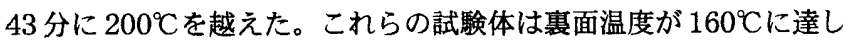
た後、約 $4 \sim 6$ 分で $200^{\circ} \mathrm{C}$ 越えている。また、この裏面温度は、 縦貫・横貫のない部分（図 1 のC 部）で測定した值だが、縦貫と横 貫の交差部（図 1 のB 部）では、これらよりも約 $15 \sim 20$ 分遅れて 裹面温度が $200^{\circ} \mathrm{C}$ を越えており、土壁の裏面温度変化は、貫等の下 地位置に大きく影響を受けることがわかった。

\section{2 土壁の各部位の仕様が防火性能に与える影䇺 \\ 3.2.1 亯返し㳂りの有無及び土塗り厚}

図 4 に裏返し塗りの有無や狳り厚の違う試験体の裏面温度変化を 示す。これによると裏返し塗りをしない土壁 $(40 \mathrm{~mm}$ 厚) と裏返し 塗りをした土壁 $(60 \mathrm{~mm}$ 厚) とでは、加熱開始 30 分以降の裹面温 度上昇が大きく異なっている。これは、裏返し鉒りがあって、厚み にほぼ同様の差がある $60 \mathrm{~mm}$ 厚・ $78 \mathrm{~mm}$ 厚の土壁の裏面温度上昇 と比較しても顕著である。裏返し塗りがない土壁では、横・縦貫や 木舞竹が加熱側（室外側）に露出しており、加熱を受けると短時間 のうちに燃焼し始める。貫や木舞竹の部分は、その厚みだけ土が薄 いので、それらが炭化し落下した後は裹面への熱伝達が促進され、 裏面温度が上昇し易くなると考えられる。加熱面では、加熱開始 10 分頃から木舞竹、20 分頃から貫が落下し始めており、土壁の熱貫流 の時間遅れを考虑すると 30 分以降に裹面温度の差が顕著に現れる のはその影響と考えられる。

また、表 2 によれば、裏返し塗りがない土壁 (40mm 厚) の裏面 温度が $160^{\circ} \mathrm{C}$ 達する時間は、壁厚やちちり周りの処理の工夫に対し て系統的な変化を示さず、加熱開始後 $25 \sim 34$ 分とばらつきがみら れる。裏返し鉒りがない場合、片側からのみ土を塗るので、反対側 は木舞竹の阥間から土がはみ出して、木舞竹に食らいつき、壁とし て一体になる。このはみ出す土の量は荒壁を塗る強さによって異な る。実験直前の試験体重量は、加熱開始後 34 分に車面温度が $160^{\circ} \mathrm{C}$ を越えた試験体No.10 が $49.35 \mathrm{~kg}$ 、同様に 25 分に越えた No. 12 が $44.15 \mathrm{~kg}$ と約 1 割の差が生じている。軸組はほぼ同じ仕様なので、 この差は筀った土の重量と考えられ、仕上げ側の土の厚みが同じで あれば、反対側にはみ出した土の量が増加したと考えられる。木舞 竹からはみ出す土量が多いとそれが自重で垂れて貫や木舞竹に覆い 被さるので、貫や木舞竹が直接加熱される部分の表面積が減少し、 炭化後も落下しにくくなると考えられる。この影響で裹面温度の上 昇にばらつきが生じたと考えられる。

\subsection{2 土の種類及び含水率}

図 5 に本実験で使用した 3 種類の土の莗面温度変化を示す。これ によると荒木田土のほうが媣草土よりも裹面温度上昇が緩慢で、土 の種類が土壁の遮熱性能に影響を与える可能性がある。また、図 6 に裹返し㙦りをしない土壁の含水率の違いによる裏面温度の変化を 示す。これによると裏面温度が $100^{\circ} \mathrm{Cに}$ 達するまでは含水率に差が あっても大きな違いは見られないが、それ以降は含水率 $10 \%$ の方が 土壁に含まれる水分が多い分、蒸発潜熱を奪われて温度は $100^{\circ} \mathrm{C}$ 付

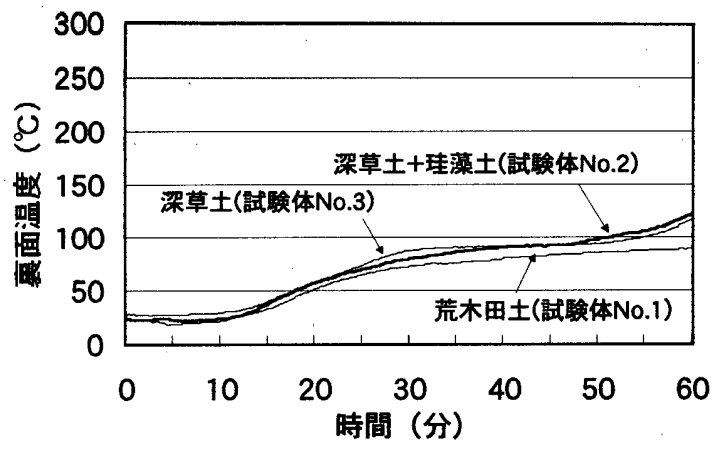

図 5 土の逴いによる裹面温度変化

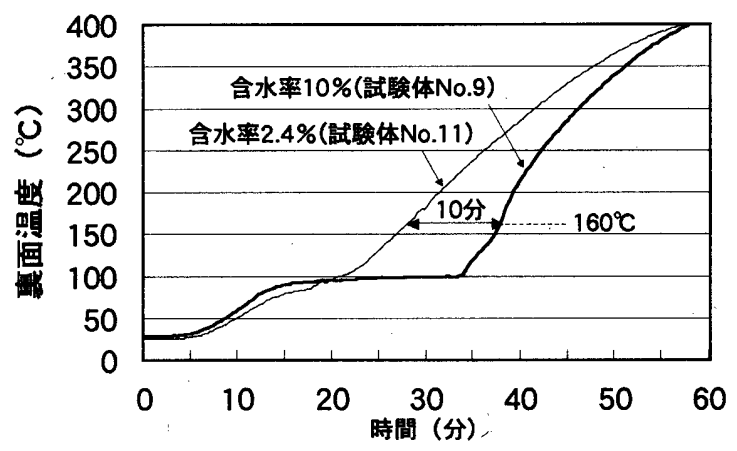

図 6 土の含水率の䕗いによる裹面温度变化

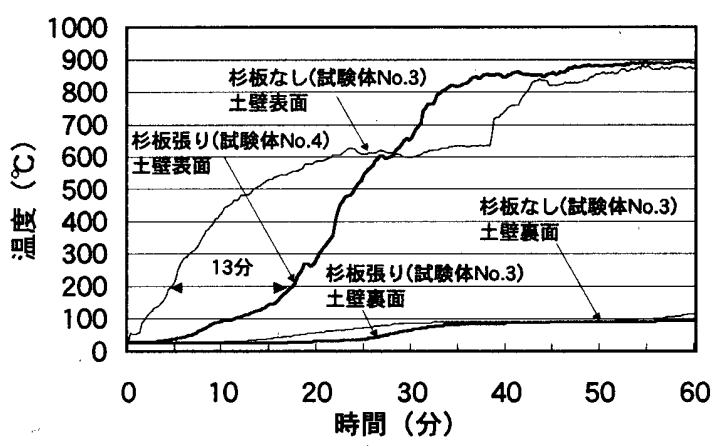

図 7 外部仕上げの有無による温度変化

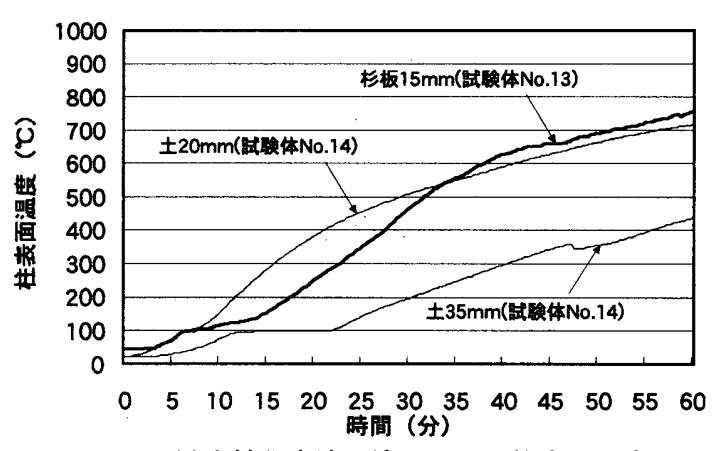

図 8 防火被覆方法の違いによる柱表面温度変化

近で停滞する。裏面温度が $160^{\circ} \mathrm{Cを}$ 越す時刻を比較すると含水率 10 \%の方が約 10 分遅くなる。

\subsection{3 外部仕上げの有無}

図 7 に裏返し叙りのある土壁（試験体No.8）とその表面に杉板 $12 \mathrm{~mm}$ 厚を張った場合（試験体 No.4）の土壁表面温度及び裏面温 度の変化を示す。これによると $12 \mathrm{~mm}$ 厚の杉板を張った場合、板が 燃え抜けるまでは土壁や柱の表面は直接加熱されないので、土壁表 面が $200^{\circ} \mathrm{C}$ を越す時刻で比較すると張らない場合よりも約 13 分の加 
热遅延効果があることがわかる。同様の理由で裹面温度の上昇も緩 やかになっている。また、木材の炭化速度の慣用值 $0.6 \mathrm{~mm} /$ 分 ${ }^{61 な}$ から単純計算すると $12 \mathrm{~mm}$ 厚の板が燃え抜けるのに 20 分を要する ことになるが、実験中の加熱面をみると相じゃくりで縱張り施工し た板の取り合い部から先に然え抜けており、土壁表面に張った板の 施工方法が燃え抜け時間に影響を与える可能性がある。

\subsection{4 柱の防火被覆・準不燃薬郕処理}

柱に土や木材で防火被覆をした場合の柱表面の温度変化を図 7 に、 柱に準不燃楽剤処理や防火塗料を叙布した試験体の加熱終了後の炭 化状況図を図 11(a)〜(d)に示す。まず、図 8 をみると柱表面が 200 Cをを越える時間は、土 $20 \mathrm{~mm}$ (試験体 No.14）－板 $15 \mathrm{~mm}$

(No.13） $\rightarrow$ 土 $35 \mathrm{~mm}$ (No.14) の順に荤くなっている。同程度の厚 みであれば、不燃材料の土よりも木材の方が、防火被覆の効果が大 きいことがわかる。ところで、杉板 $15 \mathrm{~mm}$ 厚では、 $200^{\circ} \mathrm{C}$ を越える のに約 18 分かかっている。これ以降に柱の燃焼が始まると考えら れるが、既往の報告 ${ }^{2}$ では、105mm 角のスギ柱に長期許容応力度 に相当する $21.7 \mathrm{kN}$ の荷重（めりこみ荷重）をかけて加熱試験を 行った場合、柱前面から約 $9 \mathrm{~mm}$ の部分が炭化したときに柱の座屈 が起こっている。0.6mm/分で炭化が進むとすると、柱が燃焼し始 めて約 15 分で座屈が起こったと考えられる。そうであれば、杉板 $15 \mathrm{~mm}$ 厚を $105 \mathrm{~mm}$ 角柱に防火被覆することにより、耐火加熱 30 分を越える非損傷性を実現できる可能性があると考えられる。

次に図 11(a)(b)をみると、60 分間加熱後の炭化深さは、含水ホウ 酸塩・無機リン酸系薬剤で準不燃処理をした柱で $32 \mathrm{~mm}$ (炭化速 度 : $0.53 \mathrm{~mm} /$ 分)、未処理の柱で $41 \mathrm{~mm}$ (炭化速度 : $0.68 \mathrm{~mm}$ / 分）となった。また、図 $11(\mathrm{c})(\mathrm{d})$ によると 30 分間加熱後の炭化深さ は発泡系防火塗料を塗布した柱で $21 \mathrm{~mm}$ (炭化速度 : 0.70 $\mathrm{mm} /$ 分)、未処理の柱で $25 \mathrm{~mm}$ （炭化速度 : $0.83 \mathrm{~mm} /$ 分）となっ た。これらは、加熱時間がそれぞれ異なるので、処理方法の違いに よる燃焼抑制効果を単純には比較はできないが、どちらにしても未 処理の柱より炭化を軽減させる効果があることがわかる。ただし、 この薬剤による炭化抑制効果を長期的に維持するためには、耐久性 の検討が必要である。

\section{2 .5 ちり周り部の防火的補強}

図 9 にちり周り部に様々な補強をした裹返し塗りのない試験体の 裏面温度（ちり周り部）変化を示す。これによると、伝統的な手法 であるちりじゃくりは $6 \mathrm{~mm}$ 深さより、9mm 深さのほうがより遮 熱効果を期待できることがわかる。また、布連打ちは、15

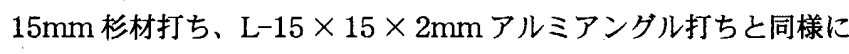
60 分間加熱を行ってもちり周り部の裹面温度は $200^{\circ} \mathrm{C}$ 以下であり、 既存建物等で柱にちりじゃくりがういていない場合でも、改修時に ちり周り部に布連打ち等の防火的補強を行えば、十分な遮熱及び遮 炎効果を期待できることがわかる。

\subsection{6柱に対する土壁の位置}

柱に対する土壁の位置が異なる試験体の炭化状況図を図 11(d) (e)に示す。これによると、炭化深さは、30 分加熱を行ったちり寸 法 $15 \mathrm{~mm}$ の試験体 No.16で $21 \mathrm{~mm}$ (炭化速度 : $0.70 \mathrm{~mm} /$ 分)、同 ビくちり寸法 $60 \mathrm{~mm}$ の No.15 で $25 \mathrm{~mm}$ （炭化速度 : $0.83 \mathrm{~mm} /$ 分） となった。炭化面積の柱全体面積に対する割合も、試験体 No.16で $17.0 \%$ 、同じくNo.15 で $26.2 \%$ となった。このことから、柱と土

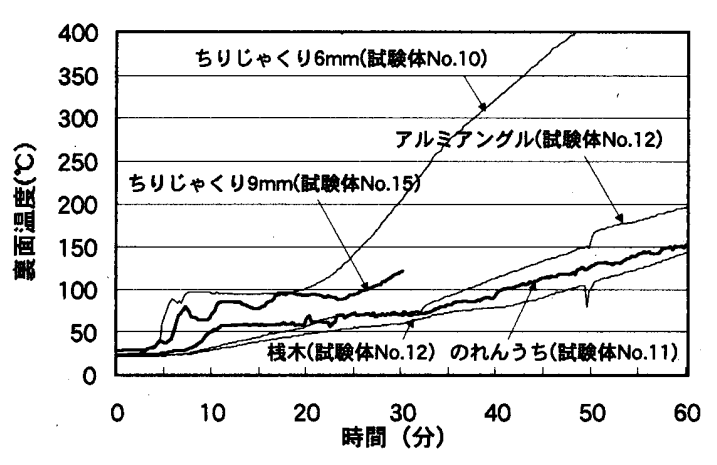

図 9 ちり周り部の補強方法の違いによる哃面温度変化

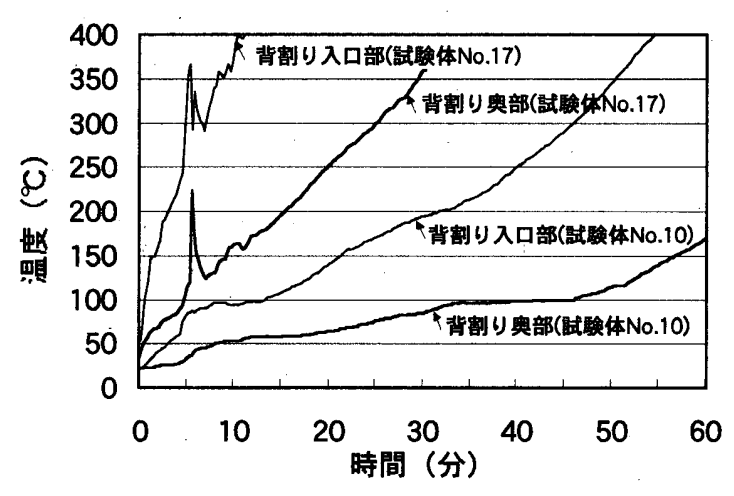

図 10 土壁の配置による背割り部の温度変化

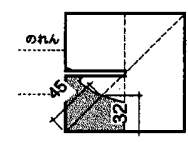

(a)試験体 No.11 柱 2 (60 分加熱)

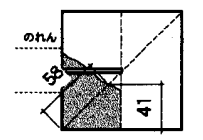

(b)試験体 No.11 柱 1 (60 分加熱)

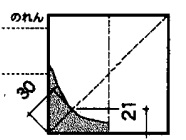

(c)試験体 No.17 柱 1 (30 分加熱)

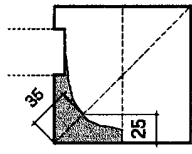

(d)試験体 No.15 柱 1 (30 分加熱)

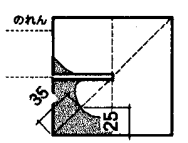

(f)試験体 No.17 柱 2 (30 分加熱)

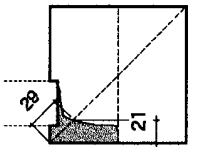

(e)試験体 No.16 柱 1 (30 分加熱)

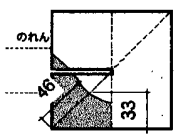

(g)試験体 No.9 柱 2 (60 分加熱)
*柱こと朼較を容易にするために柱 1 は左右反転させて表示する。 *耐火妒に試䀫体を䧣間なく装着するために柱の端部を不燃材で被得 したので、炭化状況はこの被覆の影稫を受けない半分のみ表示する。

図 11 加熱後の炭化状況図 
壁のちり寸法が小さいほど、2 面加熱される柱の表面積が減り、炭 化深さ・炭化面積ともに減少することがわかる。

\subsection{7 柱の背割り}

背割りが直接加熱される試験体 No.17 と背割りが土の中心付近に 配置されたNo.10の背割り入口及び奥部の温度変化を図 10 に示す。 これによると試験体 No.17 では約 15 分で背割り奥部の温度が 200 ○を越えているのに対して、No.10では、60 分加熱しても $200^{\circ} \mathrm{Cに}$ 達していない。すなわち、背割りが直接加熱を受ける位置にある と、背割り内部でも熱分解が進み、図11(f)のように背割り入口付近 の炭化量が增加することがわかる。また、背割りがある場合でも土 の中央付近に配置されていて直接加熱を受けなければ、背割りがな い場合とほぼ同様の炭化性状となる。

\section{2 .8 柱の樹種・寸法・含水率}

柱の炭化速度は表 2 によると、樹種とは関係なく炭化速度の慣用 值 $0.6 \mathrm{~mm} /$ 分に近く、 $0.48 \sim 0.83 \mathrm{~mm} /$ 分となった。ただし、炭 化深さは、柱と土壁のちり寸法が大きいほど、深くなる傾向が見ら れた。これは、柱が加熱されるとコーナー部は 2 面加熱を受けるが、 柱と土壁のちり寸法が大きいとこの影響を受けやすく炭化が促進さ れるからと考えられる。また、105mm 角と $120 \mathrm{~mm}$ 角の柱寸法の 違いによる然え方・炭化速度に違いは見られなかったが、同じ炭化 面積であれば、構造耐力に与える影響は断面積の小さな $105 \mathrm{~mm}$ 角 のほうが大きいはずである。また、柱の含水率が $26.9 \%$ の試験体 No.9（図 11(g)）の炭化深さは、60 分加熱で 33mm（炭化速度 : $0.55 \mathrm{~mm} /$ 分)、含水率が $13.9 \%$ の試験体 No.11（図 11(b)）で $41 \mathrm{~mm}$ （炭化速度 : $0.68 \mathrm{~mm} /$ 分）となっており、含水率が炭化深 さに与える影響が大きいことがわかる。

\section{4. まとめ}

土壁の仕様や納まりが防火性能に及ぼす影響を把握するために ISO834 標準加熱曲線に準じた加熱試験を行った結果、以下のよう な知見を明らかにした。

\section{1 遮熱性 · 遮炎性}

(1)裏返し塗りをしない土壁・裹返し塗りをした土壁ともに、表 3 の ように現行法令を上回る防火性能を確認できた。ただし、防火上 もっとも不利な裹返し叙りのない土壁では、遮熱性能を確実に保証 するためには、塗り厚や土量の確保が重要である。

\section{表 3 实験結果から推測される土壁の防火性能}

\begin{tabular}{|c|c|c|}
\hline 仕溙 & $\begin{array}{l}\text { 現行の建穼基準 } \\
\text { 法上の位粗付け } \\
\end{array}$ & $\begin{array}{c}\text { 本実験から推測される } \\
\text { 遮熱·遮炎性能 }\end{array}$ \\
\hline 串返し塗りのない土壁 & 準防火性能*1 & 防火椿造 \\
\hline 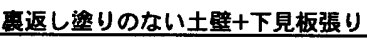 & 準趽火性能*1 & 防火構造 \\
\hline 直返し㬁りのある土壁 & 防火柍造 & 準耐火栭造（60分） \\
\hline 曹返し魚りのある土璧十下見板镸り & 防火構造*1 & 準耐火慄造 (60分) \\
\hline
\end{tabular}

(2)ちり周りの経年変化による隙間防止のために伝統的に行われてき たちりじゃくりや布連打ちは防火的補強方法としても有効である。 また、既存建物で柱にちりじゃくりがない場合でも、改修時に布連 打ち、栈木打ちなど行えば防火上弱点となるちりまわりの遮熱性 . 遮炎性能の向上が可能である。

（3）大壁となるよう土壁の表面に杉板を張ると、土壁や柱への加熱が
遅延される。

(4)土の含水率は、遮熱性能に大きな影響を与える。

（5）土の種類は、遮熱性能に影響を与える可能性がある。

\section{2 非損傷性}

非損傷性の評価に大きな影響を与えると考えられる柱の炭化性状 について、次の知見を明らかにした。

(1)柱の炭化速度は、材種毎に大きな違いはみられず、木材の炭化速度 の慣用值 $0.6 \mathrm{~mm} /$ 分 $\left.^{6}\right)$ に近い值 $(0.48 \sim 0.83 \mathrm{~mm} /$ 分）となった。 (2)柱を木材や土で防火被覆すると、柱の燃焼開始時刻を遅延する効 果がある。本実験では、土 $20 \mathrm{~mm}$ 厚 $\rightarrow$ 杉板 $15 \mathrm{~mm}$ 厚 $\rightarrow$ 土 $35 \mathrm{~mm}$ 厚 の順でこの効果が増大した。

（3)柱と土壁のちり寸法を小さく（柱側面の露出面積を小さく）する と、炭化を軽減させることが可能である。

(4)柱の背割りが值接加熱される位置にある場合、ない場合と比較し て背割り周辺の炭化面積が若干増加する。しかし、柱に背割りがあ る場合でも、土壁の中央付近で直接加熱を受けなければ、背割りが ない場合と燃焼性状はほとんど変わらない。

(5)柱を含水木ウ酸塩・無機リン酸系薬剤で準不燃材化処理したり、 表面に発泡系防火塗料の塗布すると、柱の燃焼を抑制または遅延 し、炭化を軽滅させることが可能である。ただし、この薬剤による 効果を長期的に維持するためには、耐久性の検討が必要である。

\section{解辞}

本研究は、（財）旭硝子財団による研究助成「再生再利用可能な 長寿命市街地建築としての木造土壁構法の技術整備指針に関する研 究」の一環として行われた。試験体計画・製作にあたり、佐藤左官 工業所の佐藤嘉一郎氏、加藤左官工業の加藤信吾氏、京都府建築工 業協同組合の堀榮二氏、実験にあたり、京都大学木質科学研究所の 石原茂久名誉教授、川井秀一教授、（財）日本住宅・木材技術セン 夕一の山田誠氏、早稲田大学長谷見研究室の太田英輔氏、酒井憲吾 氏、樋山恭助氏、清水真理子氏、尾野克典氏、並びに(株)東亜理科、 木材準不燃材化処理及び防火塗料メ一カーの関係各位に多大なるご 助言・ご協力を賜わりました。記して深く感謝の意を表します。

注 1 本実験では、試験体初期温度は $20 \sim 30^{\circ} \mathrm{C}$ あったので、安全側評価と なるよう、初期温度を $20^{\circ} \mathrm{C}$ と設定し、遮熱性評価の規定値を裹面平均温度 $160^{\circ} \mathrm{C}$ 、最高温度 $200^{\circ} \mathrm{C}$ とした。

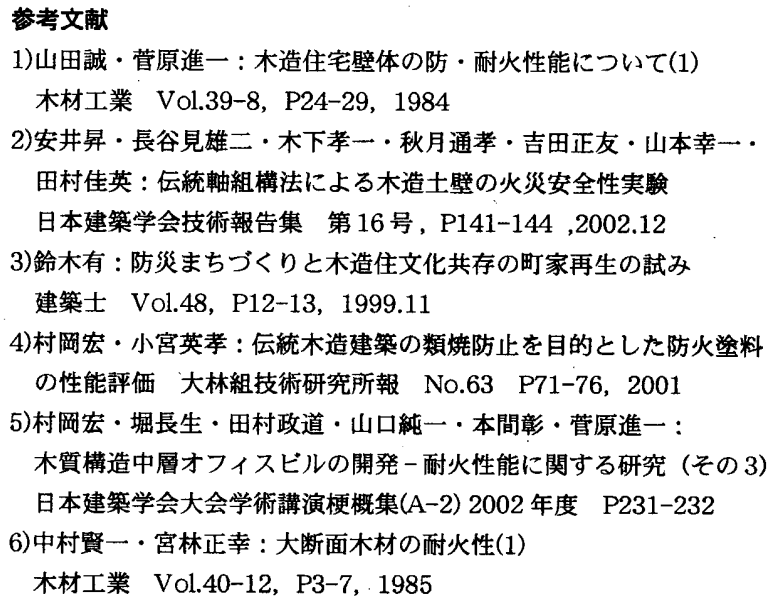

(2002年12月 9 日原稿受理， 2003 年 2 月 3 日採用決定） 